\title{
Proclus the Philosopher and A Weapon of Mass Destruction: History or Legend?*
}

\author{
JOHN DUFFY
}

The chronicler John Malalas, in his coverage of the imperial years of Anastasius I (491-518), provides a long and lively account of the protracted revolt of the Thracian Vitalian against the emperor a few years before the end of the reign (515). ${ }^{1}$ Matters came to a head when the rebel and his forces took their positions across the Golden Horn in Pera, intending to attack the heart of the capital from there. At that crucial point the emperor, exasperated and out of ideas, decided to call in outside help, in an episode described by Malalas as follows: "The emperor Anastasios had formerly summoned, through Marinus, the philosopher Proclus of Athens, a famous man. The emperor Anastasios asked him, 'Philosopher, what am I to do with this dog who is so disturbing me and the state?' Proclus replied to him, 'Do not despair, emperor. For he will go away and leave as soon as you send some men against him.' The emperor Anastasios immediately spoke to the exprefect Marinus the Syrian, who was standing close by while the emperor was conversing with the philosopher Proclus, and told him to prepare for battle against Vitalian who was then opposite Constantinople. The philosopher Proclus said to Marinus the Syrian in the presence of the emperor, 'Take what I give you and go out against Vitalian.' And the philosopher ordered that a large amount of what is

* I wish to thank Dominic O’Meara, Eustratios Papaioannou, and Mark Schiefsky for useful discussions on the theme of this paper; none of these scholars, however, is responsible for the views expressed herein. Christopher Jones kindly helped me out on a point of historical geography.

1 Throughout, the Greek text of Malalas will be cited from the edition of J. Thurn (ed.), Ioannis Malalae Chronographia (CFHB XXXV - Series Berolinensis), Berlin/New York, 2000. Unless otherwise stated, all parts of the chronicle quoted in English are taken from the Australian translation, The Chronicle of John Malalas: A Translation, by E. Jeffreys/M. Jeffreys/R. Scott (Byzantina Australiensia 4), Melbourne, 1986. Both works are cited according to the sections of the Dindorf edition (Ioannis Malalae chronographia. Ex recensione L. Dindorfii [CSHB], Bonn 1831), the only form of reference to Malalas that the two modern works have in common; the Dindorf numbers are found at the head of each page in Thurn, and are printed in bold type in the body of the Australian translation. 
known as elemental sulphur be brought in and that it be ground into fine powder. He gave it to Marinus with the words, 'Wherever you throw some of this, be it at a building or a ship, after sunrise, the building or ship will immediately ignite and be destroyed by fire.",2

To make a long story short, Marinus mustered a fleet of ships, loaded them with armed men and a supply of sulphur. The rebel Vitalian, for his part, set out with his troops and ships to attack the city. The two fleets met at the third hour of the day in the waters opposite Sycae, the sulphur powder was deployed, most of the rebel ships burst into flames and sank to the bottom of the Bosphorus, Vitalian quickly fled the scene and the city was saved.

The chronicler then closes the account with a few short remarks, in one of them returning to the inventor of the marvelous weapon: "The philosopher Proclus the Athenian successfully sought permission from the emperor to leave, and refused to accept anything from the emperor, who had in fact ordered that he should receive four hundred pounds of gold. The philosopher returned to his own city of Athens where he immediately died.",

The reactions of scholars to this report, as a piece of history, have been brief, fairly consistent, and understandable. Representative views are those of J. B. Bury and the editor of the Prosopography of the Later Roman Empire. The former comments in a footnote to his Later Roman Empire, that the Athenian man of science is "not to be confounded with the famous Neoplatonist who had died in A.D. $485 " ;{ }^{4}$ and the Prosopography, assigning a separate entry to a Proclus, philosopher, says "possibly a native of Athens; . . . in 515 he contributed to the naval defeat of Vitalianus outside of Constantinople." 5 Those comments are under-

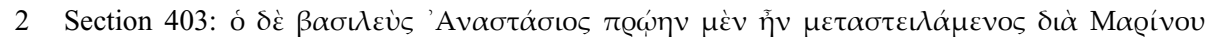

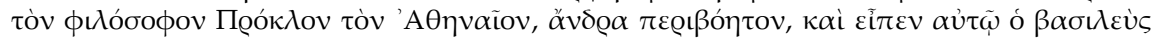

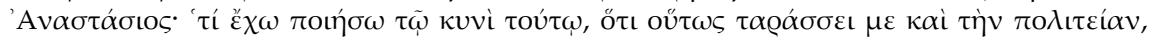

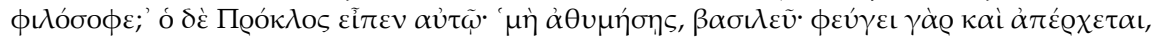

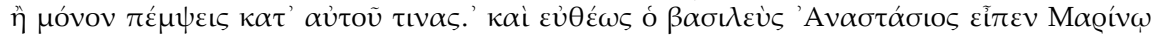

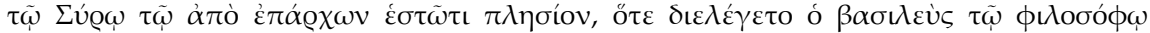

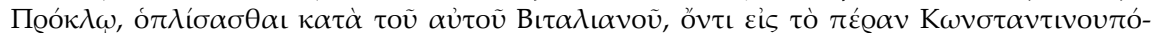

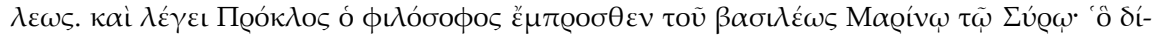

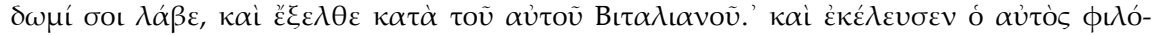

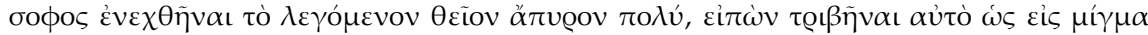

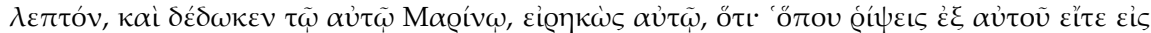

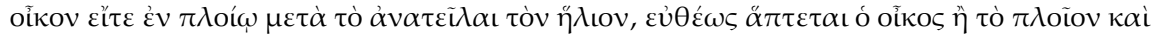

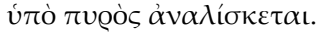

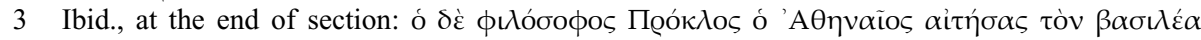

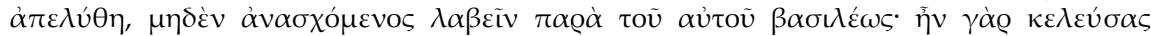

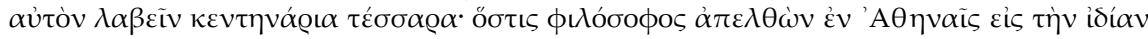

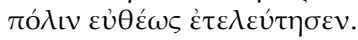

4 J. B. Bury, History of the Later Roman Empire, London 1931, I 452, n. 1.

5 PLRE 2, Proclus no. 8. 
standable because historians and prosopographers, when they read chronicles and histories, normally expect to be dealing with more or less factual narratives of the past. Obviously, then, an individual, who by general agreement died in 485 , could not be still active in the year 515, and therefore must be a different person.

My purpose here is to raise a serious question about the Malalas story and to offer a set of reasons in support of a new interpretation. The fundamental question is this: does the episode of the emperor and the philosopher deserve to be treated as an account of an actual event?

My view is that it does not, and I am also of the opinion that the man at the center of the story, the weapon-inventing philosopher, is (or more strictly speaking, is imagined to be) the Neoplatonist Proclus of the previous generation. It is not going to be possible to provide a series of straightforward positive proofs, but I hope that the considerations offered will be convincing enough to place the main contention on a firm footing.

The central argument to start the process will be based on plausibility and on the name of the individual in question. Simply put, how likely is it that there were two philosophers from Athens, by the name of Proclus, both deserving the description of "famous", living within 30 years of each other, and yet one of them would be entirely lost to history were it not for the unique testimony of the chronicler Malalas? ${ }^{6}$ Not very likely, one may say with no little confidence.

Let me cite something of a parallel phenomenon. There is a passage in the History of Attaleiates (11th cent.) recording the death of a man who is described as "Michael the monk, the hypertimos, a leader in political affairs, tò $\gamma \varepsilon \dot{v}$ os

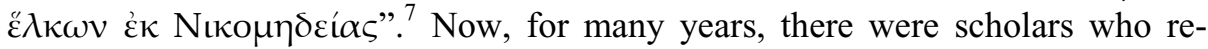
fused to accept that this obituary notice was referring to Michael Psellos, partly

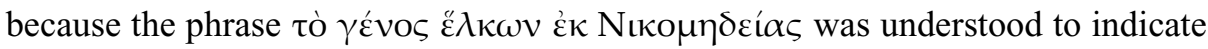
the man's birthplace, which would be in conflict with the generally accepted view that Psellos was a native of Constantinople. But Apostolos Karpozilos, in a recent article, shows this to be a groundless objection. He points out that the phrase in question, as used five times by Attaleiates, consistently refers to family background and not to birthplace. And so Karpozilos sums up the situation nicely, as follows: "But if Attaleiates did not imply Psellos at this point whom could he possibly have in mind? From the historical sources of this period there is only one

6 Unique, in the sense that Malalas is the earliest and only independent source for the story of Proclus and the sulphur weapon.

7 Michael Attaleiates, Historia. Introducción, edición y comentario de I. Pérez Martín (Nueva

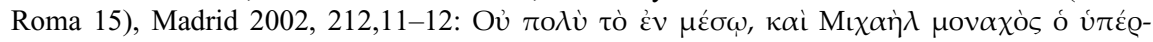

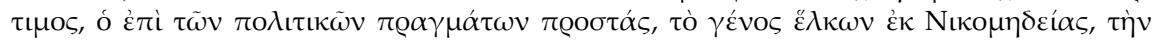

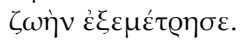


monk named Michael, who had received the dignity of hypertimos and was actively involved in politics - Michael Psellos."

The case of Proclus is, I suggest, equally strong. For it is well nigh undisputable that in Byzantium there is only one "philosopher Proclus" and he is often cited in these terms alone, without the additional marker "Athenian". In the present

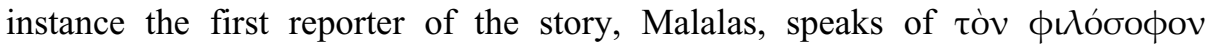

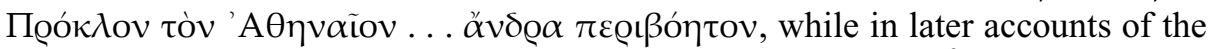
Vitalian episode he is simply called "the philosopher Proclus". ${ }^{9}$ It is exactly the same with regard to the equally famous Iamblichus. The Byzantines know only one philosopher by that name, often referred to without the addition of "philosopher". Proclus, by contrast, did have a distinguished namesake earlier in the fifth century, the bishop who held the see of Constantinople (died 446/447); hence the need sometimes to avoid possible misunderstanding and to add a marker either of place or profession. And we should return to the other descriptive adjective

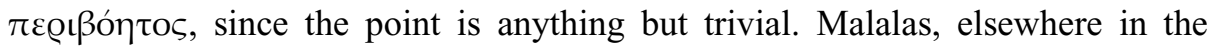
Chronicle, uses it a mere six times for other people and the list (with one possible exception) will show how renowned the bearers are: Orpheus, Zoroaster, Dionysius the Areopagite, the Roman Asclepion, Libanius, and Hypatia of Alexandria. ${ }^{10}$ The evidence here would suggest that he applies the word sparingly and almost exclusively to individuals who enjoy the highest recognition. The conclusion,

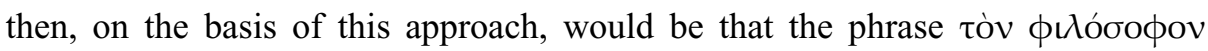

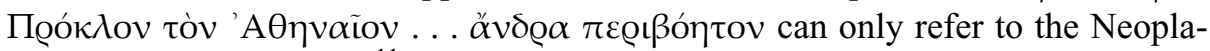
tonist Proclus (died 485). ${ }^{11}$

Assuming that this position is acceptable for the moment, then the following issues must be immediately confronted: if the Malalas text really has in mind the renowned Proclus of Athens, the Neoplatonist, how are we, first of all, to react to the surprising news that the philosopher developed a prototype of "Greek Fire" for which the Chronicle is the only independent source? And secondly, how are we to deal with the impossible scenario of his having accomplished such a noteworthy feat all of 30 years after his own death?

My solution to the first difficulty is to claim straight out that we have to do here, not with history, but with imaginative fiction. We are dealing with a legend

8 A. Karpozilos, When did Michael Psellus die?, in: BZ 96 (2003) 671-677 (for here, 673).

9 E. g. in Georgii Monachi Chronicon ed. C. de Boor; corr. cur. P. Wirth, Stuttgart 1978, 619, 19 and Leonis Grammatici chronographia, ex recogn. I. Bekker (CSHB), Bonn 1842, 119, 1.

10 Section $72 ; 15 ; 251 ; 266 ; 327$; and 359 respectively.

11 One might suggest that the matter is on a similar level of clarity (from the Byzantine perspec-

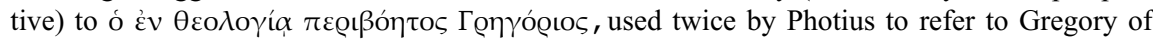
Nazianzus (Photius, Bibliothèque. Texte établi et traduction par R. Henry, Paris 1959, cod. 228, $246 \mathrm{~b}$ and Photii patriarchae Constantinopolitanae Epistulae et Amphilochia rec. B. Laourdas/L.G. Westerink, Leipzig 1983, ep. 2, 154). (Cf. A. Rhoby in this volume, 411). 
associated with the somewhat controversial emperor Anastasius, developed possibly by Malalas himself, but much more likely drawn from a story already in circulation in either oral or written form. We will consider later why Proclus might be an appropriate figure in such a setting; for now we will simply note that the idea is in tune with a fairly common motif encountered in Byzantine chronicles, one to which we could give the general label "philosophers, scientists and magicians in the service of rulers and society."

The second difficulty may be alleviated in a couple of ways. For one thing we can have recourse to a principle that I would like to express in the following terms: "strict chronology is largely irrelevant to the mythopoietic mind." In other words, the creator of an imaginative story will not be constrained by cares for historical accuracy or strict chronology. One could cite numerous examples; I will briefly allude to two.

For centuries there circulated throughout Byzantium (and in the West also) a legend about the death of Julian the Apostate. ${ }^{12}$ The core of the story relates that Julian, on his way to the Persian campaign, stopped off in Caesarea to visit bishop Basil the Great and that Basil had an ominous vision in which the emperor was slain by St. Mercurius. That account made the rounds for ages, without raising an eyebrow, and it was not until the 12th century that the critical minded Michael Glykas pointed out the chronological impossibility: Basil was not yet the bishop of Caesarea at the time of Julian's reign; in fact he assumed the see only some seven years later. ${ }^{13}$

Another consideration is the modus operandi of those who compose chronicles. The late Jacob Ljubarskij, in an article discussing the narrative techniques of George the Monk in the ninth century, pointed to several episodes in George's work that were deliberately placed out of historical context. ${ }^{14}$ In one case, a story as told by John Moschus and set around the year 400, was transferred nonchalantly by George to the reign of Constantine III in the 640's. In another instance, blithely ignoring historical background, George took an event connected with the time of pope Gregory I (590-604) and retold it in the context of the reign of Leo the Isaurian (717-741). Ljubarskij calls this phenomenon "chronological displacement" and it can also be applied to what Malalas, or his source, has done in the case of Proclus.

But it is not just "chroniclers" who can be oblivious to chronological niceties. If one were to ask which Byzantine of the medieval period was most attuned to Proclus the Neoplatonist and his thought, the answer would most likely be Mi-

12 One of the best treatments of the story is still that by N. H. Baynes, The Death of Julian the Apostate in Christian Legend, in: JRS 27 (1937) 22-29.

13 Michaelis Glycae annales, recognovit I. Bekker (CSHB 24), Bonn 1836, 471.

14 J. Ljubarskij, George the Monk as a Short-Story Writer, in: JÖB 44 (1994) 255-264. 
chael Psellos. But consider the section on the reign of Anastasius in the Historia Syntomos of Psellos: "Under his rule flourished the great Proclus the philosopher whom I consider second after Plato. He was a pupil of the wise Syrianus, but he exceeded his teacher by far and raised Greek wisdom to his own standard. $\mathrm{He}$ studied all the works of Archimedes, but invented many things that had remained unknown to Archimedes. Thus he had fire-bearing mirrors of bronze placed upon the walls; from there he fired thunderbolts upon the barbarians who besieged the city." 15

Psellos' chapter on Anastasius, of which we have quoted only the middle part, is an intriguing combination of disparate elements. The section on Proclus is actually sandwiched between two mentions of the emperor's impious religious leanings: from the point of view of the orthodox he belonged to the Severan heresy and had tried to make an infamous addition to the Trisagion hymn. For our topic what jumps out immediately is the fact that Psellos without qualification dates the floruit of Proclus to the reign of Anastasius, flying in the face of the fact that the philosopher died a full six years before Anastasius came to the throne. One could try to explain this in any number of ways - e.g. that Psellos composed the work as a young man and made a mistake, or that the error was long entrenched in the chronographic tradition, and so on. But the bottom line does not change; that is to say, even Psellos associates the Neoplatonist Proclus with the era of Anastasius. We should therefore be prepared to accept the dislocation, $a$ fortiori, when it shows up in Malalas.

There is a second, equally interesting, development in the Historia Syntomos passage, if my interpretation of it is correct. Here we have the new information (at least I am not aware of its being reported by anyone before Psellos) that Proclus the philosopher had devised a successful system of burning mirrors, inspired by his studies of Archimedes. ${ }^{16}$ My theory, to put it in a nutshell, is this: Psellos, not

15 Michaelis Pselli Historia Syntomos, recensuit, Anglice vertit et commentario instruxit W. J.

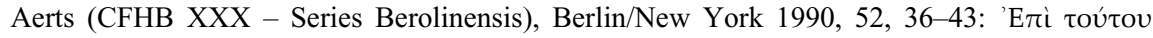

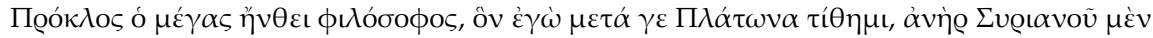

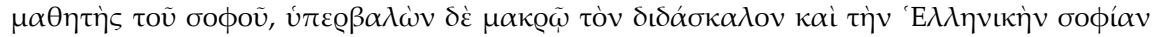

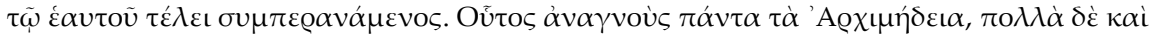

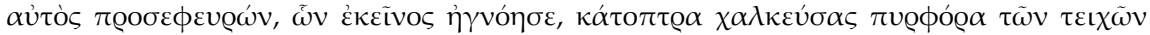

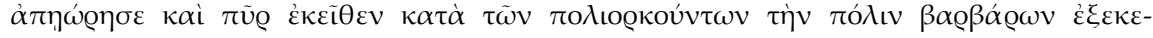

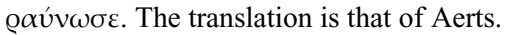

16 I will leave it to someone else to work out (if possible) a definitive solution to the problem of the relationship between the text of Psellos and the mix of authors employed by John Zonaras in the twelfth century: did Zonaras draw directly from Psellos or were both using some unknown common source? The scholar who has done most so far to confront the question is Apostolos Karpozilos. He plans to to do this in the third volume of his series on Byzantine historians and chroniclers, and has kindly let me have a preview of the relevant section. But even he has to admit in the end that the relationship is not entirely clear. For the issue at hand the correspond-

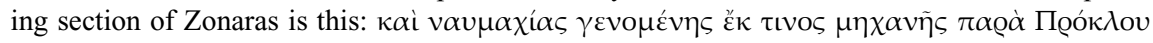


unlike the questioning Glykas in the following century, was not comfortable with the received version; in other words, the Malalas account of powder and smoke, so to say, was not to his liking and he decided to change it. A feat of engineering in the spirit of Archimedes would have been, to Psellos, a more intellectually respectable accomplishment for his philosopher hero than a chemical experiment couched in somewhat magical terms.

And "magical" is not being used gratuitously, because the text of Malalas itself could be said to contain the seeds of such an interpretation. In his closing comment on the episode the chronicler says, "There were some people in Constantinople who said that it was from the heat of the sun that the elemental sulphur, as it was so fine, caught fire, when it was thrown into the air, and that this was its nature." ${ }^{17}$ As before, this is the Australian translation of the passage. I

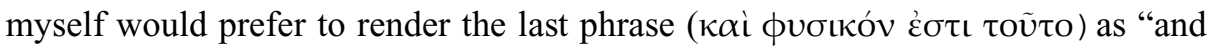
this is something natural" or "and this is a natural occurrence". In any event, what the remark as a whole seems to imply is that other people in Constantinople considered the phenomenon to be beyond the natural. And who could blame them? The Greek name for the substance, $\theta \varepsilon \tilde{c}$ ov $\alpha$ zu pretation. And the general Byzantine understanding is probably well reflected in the explanation recorded by Eustathius of Thessalonike in his commentary on the Odyssey. "Theion," he says, "perhaps because of the strange and marvellous way that it works." ${ }^{18}$ Let it also be noted that, as we learn from his student and biographer Marinus, Proclus was steeped in different kinds of ritual and theurgic practices and was the recipient of visions; among the wonders he claimed to have achieved was to produce rainfall in Attica and to have averted earthquakes. ${ }^{19}$ Finally, in the account of Malalas, the air of mystery is, if anything, enhanced by

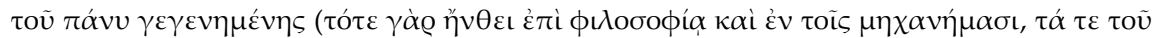

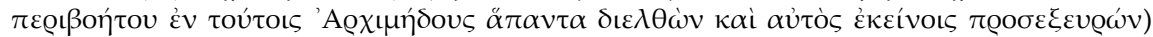

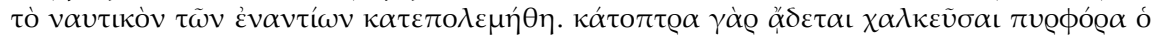

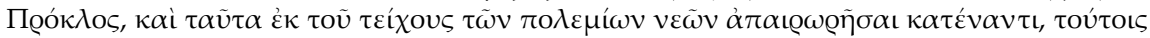

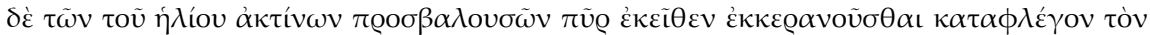

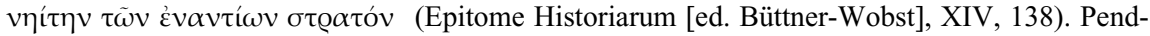
ing a full solution, my instinct persuades me to think that Zonaras had access to and used the Historia Syntomos.

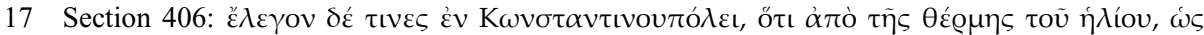

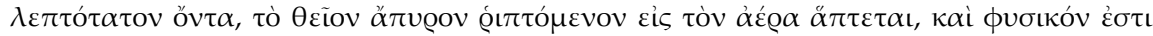

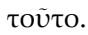

18 Eustathii archiepiscopi Thessalonicensis Commentarii ad Homeri Odysseam, edidit G. Stall-

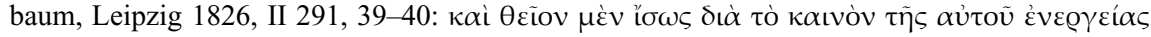

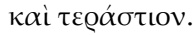

19 Marino di Napoli, Vita di Proclo, testo critico, introduzione, traduzione e commentario a cura di

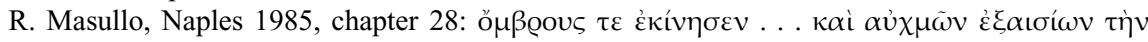

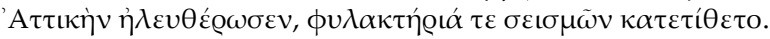


the remark that we quoted earlier, "The philosopher returned to his own city of Athens, where he immediately died."

In her study, "Malalas' World View", Elizabeth Jeffreys stresses at the outset the extent to which this sixth-century chronicler, working entirely outside the classical tradition of historiography, was molded by the intellectual environment of his own times. ${ }^{20}$ Malalas was certainly a Christian, but he seems to have been alive to a much wider spectrum of religious and superstitious thought, some of it outside the pale of orthodox theology. He weaves into the fabric of his narrative such a range of recurring types and phenomena - magoi, talismans, oracles, visions, dream interpreters, and theurgic philosophers -, that we cannot doubt the importance that he and his contemporary audience attached to these aspects of their thought world. Let us select a few representative and pertinent examples.

(Sections 151-152): Belshazzar, emperor of the Assyrians, one day had an ominous vision; he saw a man's finger writing some words on a wall of the palace and then disappear. He summoned all the sorcerers, magoi, astrologers and dream interpreters of the land, but none of them was able to unlock the meaning. Then he called in Daniel, one of the Hebrew captives, who, having received assurances of his safety, proceeded to interpret the writing as predicting the end of Belshazzar's reign. "When he heard this, Belshazzar let him go, to see if he spoke the truth. A few days later Dareios the Mede . . . attacked and killed him and captured his kingdom." (Section 233, concerning the chronicler's native city of Antioch): "Tiberius Caesar learnt that the emperor Seleukos had avoided the mountain and built the city on the plain, in fear of the floods of water coming down from the mountain in winter and forming lakes. So he added to his statue a stone box, in which he put a talisman made by Ablakka, a wonder-worker ( $\tau \varepsilon \lambda \varepsilon \sigma \tau \eta ́ \varsigma)$ and priest, to prevent the waters from the winter torrents of the river Parmenios and the streams coming off the mountain from harming that part of the city or from destroying the two great colonnades he had built." For the third example we cite the account of the reign of Julian the Apostate where Malalas records a series of three apparitions directly connected with the death of that emperor. The earliest (Sect. 327) occurred at Daphne outside of Antioch, where Julian was visiting on the way to the Persian expedition; after offering sacrifice to Apollo he lay down to sleep and saw in a vision a fair-haired youth who informed him that he was fated to die "in Asia". Later (Sects. 332-333) Malalas makes a point of recording, from a Cappadocian chronicler and participant in the expedition, a follow-up apparition in which Julian, in his sleep, saw himself being attacked by a fullgrown man in body-armor. He awoke to find himself mortally wounded and to

20 This is a chapter in E. Jeffreys/B. Croke/R. Scott (eds.), Studies in John Malalas (Byzantina Australiensia 6), Sydney 1990, 55-66 (for here, 55). 
hear from his entourage that the town in which they were encamped was called "Asia". Soon (Sects. 333-334) Malalas completes the picture by presenting his version of the dream (alluded to earlier) of Basil of Caesarea on the fateful night. Basil saw St. Mercurius, in body-armor, receiving an order from Christ to go and kill the emperor; the saint went off, and later reappeared to report that the mission had been accomplished.

It is clear from these and a small host of other episodes of similar nature that Malalas was intrigued by all kinds of strange and supernatural happenings as well as by men and women who were believed to possess expert knowledge or special powers. In two cases the individuals are designated by him as "philosopher"

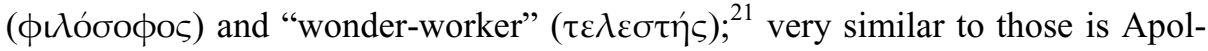
lonius of Tyana, described as "the very wise" (o $\sigma o \phi \omega \tau \tau \alpha \tau o \varsigma)$ and "performing wonders" $(\pi \circ+\tilde{\omega} \nu \tau \varepsilon \lambda \dot{\varepsilon} \sigma \mu \alpha \tau \alpha){ }^{22}$ Brian Croke, in his chapter on "Malalas' Life", speaks of a "nexus of authors and ideas of special interest to Malalas," and singles out for mention Julian the Chaldaean, Theon of Alexandria, and Iamblichus "the most Gnostic of the Neoplatonists", as he styles him. ${ }^{23}$ It could be added that each of these, in his own way, might be fairly described from the Byzantine point of view as either a "wonder-worker" (Julian) or "mystical philosopher" (Theon and Iamblichus).

Putting all of the foregoing comments together, it is not difficult to see the direction in which the argument is tending. It is my contention that the story of Proclus and the sulphur fits the pattern, so well-represented throughout the Chronicle, of the person of special talent called in or available to help at a time of crisis. The contribution of Proclus the Athenian to the defeat of the rebel Vitalian is, on this reading, not the historical good deed of an otherwise unknown philosopher, but rather an imaginative (and anachronistic) legend woven around the figure of Proclus the Neoplatonist who, whether it be as great thinker or arch villain, always loomed large in the mind of Byzantium.

This conclusion goes directly counter to the interpretation of two of the foremost Malalas experts, Elizabeth Jeffreys and Brian Croke, each of whom prefers not only to accept the story at face value, but also chooses to offer an explanation for the detailed nature of the description. They do this, not unreasonably, by having recourse to a theory of "oral informants", that is, living sources who might have supplied Malalas with information not otherwise available in written re-

21 The two are Asios (Section 109) who originally gave the famous Palladion image to Tros, the founder of Troy, and Debborios (Section 265) who made a talisman to protect the city of Antioch even against earthquakes.

22 Among the wondrous benefactions bestowed by Apollonius on many cities (Sects. $263 \mathrm{ff}$.) were talismans against the north wind, earthquakes, scorpions and mosquitoes.

23 Jeffreys/Croke/Scott, Studies (see n. 20), 1-25 (for here, 14). 
cords. For the Proclus episode the informant, according to them, could have been Marinus the Syrian himself, a fellow-countryman of the chronicler, whom Malalas "could have met ... in Constantinople, perhaps in 520." 24

In reaction to this approach I would offer two comments. Firstly, it is hardly necessary to regard the conversations between Anastasius, Marinus and Proclus as having special significance and needing to be explained by the presence of an eyewitness. As a good narrative artist Malalas, like his fellow chronicler George the Monk in a later period, has a penchant for including in his text short stories, anecdotes, and even scenes with elements of drama, e.g. pieces of dialogue and direct speech. Good examples are to be found in episodes such as these: Bellerophon and Stheneboia (Sects. 83-84); Orestes and Pylades (Sects. 135 ff.); Belshazzar and the Hebrew Daniel (Sects. 151-152); and for the historical period, the encounter between Simon Magus and the Apostle Peter (Sects. $252 \mathrm{ff}$.); and the account of Theodosius and Eudokia Athenais - featuring another Athenian philosopher (Sects. 352 ff.)! The vivid exchanges between Anastasius, Marinus and Proclus are not necessarily, then, anything out of the ordinary in Malalas. Secondly, it should be pointed out that the reconstruction of the career of Malalas, worked out by Brian Croke and including, as we have just seen (note 24), the proposition that Malalas met and knew Marinus in the capital sometime between 512 and 520, is not the most sturdy of edifices. While the attempt to squeeze from the Chronicle itself (practically our sole source for the biography of Malalas) every possible ounce of evidence about his life and work, deserves praise and admiration, the picture developed in this manner cannot be said (nor do Croke or Jeffreys assume it) to be in any respect beyond doubt.

With regard to the very different scenario presented in this paper there is still one more piece of Malalas narrative that might be seen as possibly strengthening the proposal that Proclus the weapon developer belongs more properly to the realm of fiction than that of fact.

In the Chronicle, soon after the detailing the rebellion of Vitalian, Malalas gives a report (out of chronological sequence) of the serious civil unrest that broke out in the capital in 512, when the emperor attempted to add a monophysite formula to the Trisagion. ${ }^{25}$ Rioting and murders came to an end only after a large number of those arrested were executed on the emperor's order. In the part immediately following this we are told that a short time after the civic uprising Anasta-

24 Jeffreys, in her chapter "Malalas' Sources" in Jeffreys/Croke/Scott, Studies (see n. 20), 209. Croke, Studies (see n. 20), 6: "It is arguable that Malalas' detailed version of the Greek fire used against Vitalian in 515 came from Marinus; likewise Marinus may have been the source for Malalas' account of the monophysite riot in Constantinople in 512 in which his own house was put to the torch. If so, Malalas may have been in the imperial capital around 515-520."

25 Sects. $407-408$. 
sius was troubled in his sleep by an ominous vision: an angelic looking figure, carrying a book and reading out the emperor's name, announced to him "Because of your insatiability, I am erasing fourteen. ${ }^{, 26}$ When the panic stricken Anastasius reported the vision to his cubicularius Amantius, he learned that this official too had an equally threatening dream that same night. At this point, not surprisingly, the emperor called in a dream-interpreter who explained that they both would die before long. And the dream-interpreter was - mirablile dictu - none other than Proclus the philosopher! This time, however, he is given the geographical desig-

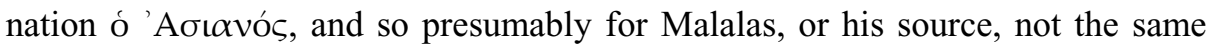
person as Proclus the Athenian. Needless to say modern historians have maintained a discreet silence about the identity of this man, but it is hardly taking a big risk to suggest that he is nothing more than a figment of the imagination. And indeed the chances are good that he has come into his imaginary existence under the influence of the real Proclus of Athens; to put it another way, he is likely to be Proclus of Athens in another guise and playing another role. ${ }^{27}$

The purpose of this exercise was to raise a serious doubt about the historicity of an episode in the rebellion of Vitalian against the emperor Anastasius, as depicted in the Chronicle of John Malalas. It has not been possible, as anticipated at the beginning, to provide hard evidence or a set of positive proofs, but we have tried to present a case for the contention that the story of the philosopher and Greek fire is just that, a story or mythos like so many others that are to be found embedded in the narrative of Malalas. And if it be accepted that the protagonist Proclus, in spite of being "out of time", is in fact the renowned Neoplatonist, then that will simply add another piece of color to the variegated image which the Byzantines had formed of him. ${ }^{28}$

26 Sects. 408-409. Aspects of this story have been looked at in a new way by G. Fatouros, $\mathrm{Zu}$ Johannes Malalas' Chronographie, in: I. Vassis/G. S. Henrich/D. R. Reinsch (eds.), Lesarten. Festschrift für Athanasios Kambylis zum 70. Geburtstag, dargebracht von Schülern, Kollegen und Freunden, Berlin/New York 1998, 61-66; see also the valuable comments of E. Papaioannou in his review of this Festschrift, in: JÖB 49 (1999) 321-322.

27 Papaioannou too, (see previous n.), would be open to this identification.

28 The interpretation offered here does not rule out the possibility that Marinus the Syrian did use some kind of chemical device in the battle against Vitalian. On the other hand, a look at his curriculum vitae as outlined in PLRE 2, Marinus no. 7, reveals that he spent most of his career in various "civil service" positions in finance and taxation, was already out of office in 515, and therefore not an obvious choice to be given (out of the blue?) an important military command at a time of crisis. Should we be a little suspicious here too? 
